\title{
KONFLIK TENURIAL PADA HUTAN LINDUNG GUNUNG SIRIMAU WILAYAH KPHL UNIT XIV KOTA AMBON
}

\section{TENURIAL CONFLICTS ON THE FOREST PROTECTED MOUNTAIN SIRIMAU KPHL XIV UNIT REGION AMBON CITY \\ Oleh}

Sylvia Sitania $^{1^{*}}$, Agustinus Kastanya $^{2-}$, Marthina. Tjoa ${ }^{3}$

${ }^{1)}$ Mahasiswa Prodi Manajemen Hutan Universitas Pattimura, , Ambon 97123

${ }^{2,3)}$ Dosen Prodi Magister Manajemen Hutan Universitas Pattimura, Ambon 97123

E-mail : svlviasitaniatimisela@gmail.com

\begin{tabular}{l|l}
\hline Diterima: 8 Februari 2020 & Disetujui: 9 Maret 2020
\end{tabular}

\begin{abstract}
Abstrak
Konflik tenurial biasanya disebabkan oleh ketidakjelasan hak-hak (hukum/tata aturan/ peraturan) yang berhubungan dengan tata laksana sistem tenurial tersebut. Penelitian ini bertujuan untuk mengidentifikasi hak-hak dalam penguasan lahan pada masyarakat adat yang berada pada wilayah KPHL Unit XIV Kota Ambon. Pendekatan deskriptif kualitatif digunakan dalam penelitian ini, dengan menggunakan analisis RaTA (Rapid Land Tenure Assessment). Potensi konflik berupa bukti klaim para pihak secara de jure dan de facto atas sistem penguasaan tanah dan sumber daya alam sangat nyata terjadi antara masyarakat adat dan pihak UPTD KPHL Unit XIV Kota Ambon.
\end{abstract}

Kata Kunci : Hak Tenurial, Hutan Lindung, KPHL

\begin{abstract}
Tenure conflicts are usually caused by unclear rights (laws / regulations / regulations) related to the administration of the tenure system. This study aims to identify land tenure rights of indigenous communities in the area of KPHL Unit XIV Ambon City. A qualitative descriptive approach was used in this study, using the RaTA (Rapid Land Tenure Assessment) analysis. Potential conflicts in the form of evidence of de jure and de facto claims by the parties over land and natural resource tenure systems are very evident between the customary community and the UPTD KPHL Unit XIV Ambon City.
\end{abstract}

Keywords: Tenure Rights, Protection Forest, KPHL

\section{PENDAHULUAN}

Hutan Lindung mempunyai karakteristik wilayah yang berfungsi lindung sehingga menjadi kawasan yang wajib dilindungi agar mampu memberikan fungsi sebagaimana mestinya. Hutan mempunyai arti penting dalam kehidupan manusia, karena hutan mempunyai fungsi ekologis, sosial dan ekonomis. Kementerian Lingkungan Hidup dan Kehutanan merupakan salah satu institusi yang diserahi tanggungjawab untuk memastikan hutan mampu menjalankan ketiga fungsi tersebut (ekologis, ekonomis dan sosial) secara seimbang agar kelestarian hutan tetap terjaga.

Dalam pelaksanaan sistem tenurial kawasan hutan, hal yang sering dijumpai adalah konflik yang biasanya disebabkan oleh ketidakjelasan hak-hak (hukum/tata aturan/ peraturan) yang berhubungan dengan tata laksana sistem tenurial tersebut. Konflik dapat terjadi antara perorangan, masyarakat, badan atau instansi pemerintah dan sektor swasta karena munculnya faktor pemicu. Salah satu faktor pemicu terjadinya konflik tenurial yaitu batas-batas kawasan hutan/ lahan yang belum disepakati antara pemilik (masyarakat) dengan pemerintah dan sektor swasta. Fakta di lapangan menunjukkan bahwa sumberdaya kawasan hutan sudah dimanfaatkan oleh masyarakat (masyarakat adat atau penduduk asli/ indigineous society), masyarakat pendatang 
dan sektor swasta yang pengelolaannya belum diakomodir, terutama dalam hal perencanaan dan pembangunan sektor kehutanan.

Pembentukan Kesatuan Pengelolaan

Hutan Lindung (KPHL) di tingkat lokal sebagai entitas manajemen secara langsung menangani permasalahan yang ada dan memberikan dasar untuk tata kelola hutan yang lebih baik dan dukungan keterlibatan pemangku kepentingan. UPTD KPHL Unit XIV Kota Ambon maka UPTD KPHL Unit XIV Kota Ambon diberi kewenangan untuk melaksanakan pengelolaan wilayah KPHL Unit XIV Kota Ambon seluas $\pm 9510.52 \mathrm{Ha}$ sesuai lampiran Peta Surat Keputusan Menteri Kehutanan Nomor SK. 66/Menhut-II/2010 dan berpedoman pada tugas pokok dan fungsi KPH sesuai Peraturan Pemerintah Nomor 6 Tahun 2007 jo. Peraturan Pemerintah Nomor 3 Tahun 2008.

Masyarakat Negeri Soya merupakan salah satu kelompok masyarakat adat yang memiliki ketergantungan yang tinggi pada hutan Lindung Gunung Sirimau, bukan saja dari aspek ekologis dan ekonomis tetapi aspek social budaya masyarakat yang telah menyatu dengan kondisi alam di sekitar hutan. Ketergantungan atas hutan telah mendorong pengaturan sistem penguasaan lahan hutan berdasarkan sistem sosial yang berlaku dalam Negeri Soya dimana hak penguasaan atas tanah dan sumber daya alam terbagi merata dalam Dati dan dikuasai oleh Soa. Petuanan adat Negeri Soya dibagi menjadi 446 (empat ratus empat puluh enam) Dati yang dipimpin oleh 42 Kepala Dati yang berasal sari Soa Parenta (Rehatta, Pesulima, Tamtelahitu dll) yang keberadaan masih diakui oleh masyarakat adat sampai sekarang ini. Sistem sosial masyarakat Negeri Soya memiliki hubungan mengatur pengelolaan hutan lestari untuk mendapatkan pemanfaatan berkelanjutan telah dipraktekkan dari zaman leluhur melalui aturan, norma dan nilai adat yang telah

\section{METODE PENELITIAN}

Penelitian dilaksanakan di Negeri (Desa) Soya, yang termasuk dalam wilayah terinternalisasi dalam kehidupan masyarakat adat yang keberadaannya tetap dijaga dan dilestarikan.

Hak pengelolaan dan akses terhadap kawasan hutan lindung Gunung Sirimau tidak hanya oleh KPHL Unit XIV Kota Ambon dan masyarakat adat tetapi juga Pemerintah Kota Ambon selaku pengelola jasa air dan masyarakat pendatang di sekitar kawasan hutan lindung Gunung Sirimau yang mendiami lokasi dusun air besar atas seijin masyarakat adat selaku pemilik lahan melalui pemerintah Negeri Soya. Tingginya hak akses antar para pihak terhadap kawasan Hutan Lindung dapat memicu terjadinya konflik tenurial akibat saling klaim atas pengelolaan tanah dan sumber daya alam dan legitimasi kepemilikan berdasarkan de jure dan de facto. KPHL Unit XIV Kota Ambon selaku pengelola mendapat legitimasi didukung oleh aturan perundang-undangan dan peraturan yang berlaku sementara masyarakat adat memiliki klaim legitimasi berdasarkan Register Dati 1814 yang merupakan produk Kolonial Belanda dalam pengatur sistem penguasaan lahan di Negeri Soya serta pengakuan hak-hak masyarakat adat yang berada dalam kawasan hutan lindung Gunung Sirimau oleh Pemerintah RepubliK Indonesia melalui putusan Mahkamah Konstitusi Nomor 34/PUU-IX/2004

Berdasarkan kondisi diatas jika persoalan terkait tenurial tidak difasilitasi penyelesaiannya antar pihak-pihak yang yang terlibat di dalam klaim penguasaan tanah dan sumber daya alam maka dikwatirkan akan menjadi salah satu penghambat dalam penataan dan pengelolaan KPHL Unit XIV Kota Ambon kedepan. Untuk itu tujuan dilakukan penelitian ini untuk mengidentifikasi hak-hak dalam penguasan lahan sehingga dengan hasil penerlitian tersebut dapat menjadi informasi dalam rencana penataan dan pengelolaan KPHL Unit XIV Kota Ambon.

KPHL Unit XIV Kota Ambon dan berada pada kawasan Hutan Lindung Gunung Sirimau. 
Penelitian dilaksanakan pada bulan Nopember 2019 sampai dengan Januari 202 Penelitianini menggunakan pendekatan diskriptif kualitatif. Pengumpulan data dilakukan melalui wawancara menggunakan kuesioner dengan anggota masyarakat yang dipilih secara purposive. Wawancara juga dilakukan dengan para pihak yang terkait dengan tujuan penelitian untuk memperkuat data yang diperoleh di masyarakat. Selain itu juga diakukan obervasi lapangan untuk melihat kondisi sesuai hasil wawancara. Kajian dokumen terkait juga dilakukan untuk memperkuat data yang diperoleh.

Analisis data dilakukan dengan menggunakan metode analisis RaTA (Rapid Land Tenure Assessment) yang dikembangkan oleh Galudra et al, (2006). RaTA digunakan untuk menilai, memahami dan menjelaskan secara sistematis bahwa di dalam wilayah KPHL Unit XIV Kota Ambon terdapat potensi konflik atau tidak yang mencakup subjek (siapa), objek (tanah dan Sumber daya alam), dan bentuk-bentuk hubungan kausal parapihak. Ada beberapa bagian penting dalam analisis potensi konflik yang menjadi kerangka yang difokuskan pada kepentingan parapihak dan sistem penguasaan tanah dan SDA, aturanaturan pengelolaan SDA yang terkait dengan hak-hak penguasaan parapihak. Selain itu akan dianalisis bagaimana hubungan diantara hakhak penguasaan parapihak apakah saling bersinergi atau saling bertolakan. Data dan informasi yang dihimpun dibagi menjadi tiga bagian pertanyaan yaitu : a) Seberapa pasti masyarakat memiliki hak-hak atas tanah-tanah tersebut?; b) Seberapa pasti pemerintah atau pihak lain memiliki hak-hak atas tanah-tanah tersebut?; c) Kebijakan-kebijakan apa saja yang mengakui atau memperkuat klaim masyarakat atas tanah-tanah tersebut, namun di lain pihak mengakui atau memperkuat klaim pemerintah atau pihak lain atas tanah-tanah tersebut?

\section{HASIL DAN PEMBAHASAN}

\section{Potensi Konflik Dalam Wilayah KPHL Unit XIV Kota Ambon}

Pihak-pihak yang secara de jure dan de facto mengklaim penguasaan tanah dan SDA dalam wilayah KPHL Unit XIV Kota Ambon yakni: UPTD KPHL Unit XIV, Pemerintah Daerah Kota Ambon dan Masyarakat adat. Hasil penilaian (assessment) terhadap hak tenurial dalam wilayah KPHL
Unit XIV menunjukan bahwa masing-masing pihak memiliki basis legitimasi klaim. Basis legitimasi klaim terdiri dari status tanah (tata kuasa), perencanaan pengelolaan (tata kelola) dan perijinan (tata perijinan). Berdasarkan hasil wawancara dan observasi, basis legitimasi klaim para pihak yang memiliki klaim dalam wilayah KPHL Unit XIV dapat dilihat pada Tabel 1.

Tabel 1. Legitimasi Klaim dalam wilayah KPHL Unit XIV Kota Ambon

\begin{tabular}{|c|c|c|c|c|}
\hline $\begin{array}{l}\text { Basis } \\
\text { Legitimasi } \\
\text { Klaim }\end{array}$ & KPHL Unit XIV Ambon & $\begin{array}{l}\text { PEMDA Kota } \\
\text { Ambon }\end{array}$ & Masyarakat Adat & $\begin{array}{l}\text { Masyarakat } \\
\text { Pendatang }\end{array}$ \\
\hline $\begin{array}{l}\text { Status Tata } \\
\text { Kuasa }\end{array}$ & $\begin{array}{l}\text { - Surat Keputusan } \\
\text { Menteri Kehutanan RI } \\
\text { Nomor 430/Kpts- } \\
\text { II/1996 tanggal } 13 \\
\text { Agustus } 1996 \text { tentang } \\
\text { Penetapan Kelompok } \\
\text { Hutan Gunung Sirimau } \\
\text { seluas 3.449 Ha dan }\end{array}$ & $\begin{array}{l}\text { - Surat Keputusan } \\
\text { Menteri Kehutanan } \\
\text { Nomor 10327/Kpts- } \\
\text { II/2002 tentang } \\
\text { Penetapan Hutan } \\
\text { Lindung Sirimau }\end{array}$ & $\begin{array}{l}\text { - Klaim secara de jure } \\
\text { Register Dati Tahun } \\
1814 \text { yang } \\
\text { dikeluarkan oleh } \\
\text { kolonial Belanda } \\
\text { - Putusan Mahkamah } \\
\text { Konstitusi Nomor } \\
\text { 34/PUU-IX/2011 }\end{array}$ & - \\
\hline
\end{tabular}




\begin{tabular}{|c|c|c|c|c|}
\hline & $\begin{array}{l}\text { Kelompok Gunung } \\
\text { Nona seluas } 877.78 \mathrm{Ha} \\
\text { sebagai kawasan Hutan } \\
\text { tetap dengan fungsi } \\
\text { Hutan Lindung } \\
\text { - Klaim secara de jure } \\
\text { SK. Menhut Nomor } \\
\text { SK.65/Menhut-II/2010 }\end{array}$ & $\begin{array}{l}\text { Pelepasan Hak } \\
\text { Nomor } \\
\text { 01/PH/CS/1986 } \\
\text { - Klaim secara de } \\
\text { facto dengan adanya } \\
\text { fasilitas PDAM di } \\
\text { sekitar lokasi air } \\
\text { besar }\end{array}$ & $\begin{array}{l}\text { - Klaim secara de } \\
\text { facto lahan telah } \\
\text { dikuasai dari zaman } \\
\text { dulu dan telah } \\
\text { ditanami oleh } \\
\text { tanaman cengkih dan } \\
\text { tanaman umur } \\
\text { panjang lainnya }\end{array}$ & \\
\hline $\begin{array}{l}\text { Status tata } \\
\text { Kelola }\end{array}$ & $\begin{array}{l}\text { Mengelola wilayah } \\
\text { KPHL Unit XIV Kota } \\
\text { Ambon seluas 9510,51 } \\
\text { Ha dengan berpedoman } \\
\text { pada Tupoksi KPH } \\
\text { berdasarkan PP Nomor } \\
6 \text { Tahun 2007 jo PP } \\
\text { Nomor } 3 \text { Tahun 2008 } \\
\text { dan berdasarkan RKTN, } \\
\text { RKTP dan RKTK }\end{array}$ & $\begin{array}{l}\text { - RTRW Kota } \\
\text { Ambon Tahun 2017- } \\
2022 \text { yang tetap } \\
\text { mempertahankan } \\
\text { kawasan hutan } \\
\text { beserta fungsinya } \\
\text { dan legal acsess } \\
\text { serta jaminan } \\
\text { perlindungan } \\
\text { terhadap DAS Hutan } \\
\text { Lindung Gunung } \\
\text { Sirimau } \\
\text { - Pengelolaan Jasa air } \\
\text { pada sumber mata } \\
\text { air di air besar untuk } \\
\text { disalurkan bagi } \\
\text { kebutuhan } \\
\text { masyarakat Kota } \\
\text { ambon dan } \\
\text { sekitarnya }\end{array}$ & $\begin{array}{l}\text { - Lahan Hutan dan } \\
\text { perkebunan } \\
\text { masyarakat Negeri } \\
\text { Soya } \pm 250 \text { Ha yang } \\
\text { telah dikeloladan } \\
\text { dimanfaatkan }\end{array}$ & $\begin{array}{l}\text { - Lahan } \\
\text { petuanan } \\
\text { masyarakat } \\
\text { adat yang } \\
\text { tempati dan } \\
\text { dikelola oleh } \\
\text { masyarakat } \\
\text { pendatang } \\
\text { atas seijin } \\
\text { Pemerintah } \\
\text { Negeri }\end{array}$ \\
\hline $\begin{array}{l}\text { Status Tata } \\
\text { Perijinan }\end{array}$ & $\begin{array}{l}\text { - IUPHH bukan kayu } \\
\text { - IUPHH Jasa } \\
\text { Lingkungan }\end{array}$ & - & $\begin{array}{l}\text { - Pemerintah Negeri } \\
\text { Soya Pemilik } \\
\text { Memberikan Ijin } \\
\text { secara lisan kepada } \\
\text { Pemerintah Kota } \\
\text { Ambon dan } \\
\text { - Pinjam pakai lahan } \\
\text { pemukiman dari } \\
\text { Pemerintah Negeri } \\
\text { melalui pemilik } \\
\text { lahan bagi } \\
\text { masyarakat } \\
\text { pendatang didusun } \\
\text { air besar }\end{array}$ & - \\
\hline
\end{tabular}

Sumber: Data Primer dan Sekunder yang diolah

Basis legitimasi klaim pada Tabel 1, menunjukan bahwa status tata kuasa para pihak memiliki perbedaan yang mendasar dimana terdapat klaim penguasaan tanah dan SDA secara de jure maupun secara de facto bahkan tidak memiliki legitimasi klaim sehingga berpotensi menimbulkan konflik para pihak, terutama pihak KPHPL Unit XIV dengan masyarakat. Perbedaan terjadi juga pada status tata kelola atas klaim penguasaan tanah dan SDA dimana berdasarkan fakta di lapangan terdapat pengelolaan oleh masyarakat dalam bentuk pemukiman dan kebun yang berada di dalam kawasan hutan lindung, sedangkan berdasarkan PP Nomor 6 Tahun 2007 jo PP Nomor 3 tahun 2008 pengelolaan 
wilayah KPH meliputi: tata hutan dan penyusunan rencana pengelolaan hutan, pemanfaatan hutan, penggunaan kawasan hutan, rehabilitasi dan perlindungan hutan.

Tata perijinan yang dilaksanakan oleh para pihak juga tidak memperlihatkan persamaan, baik dari segi pelaksanaan maupun kebijakan yang mendukungnya. Tata perijinan yang ada pada masyarakat berlaku sesuai dengan sistem hukum adat, norma yang berkembang turun temurun dan kebiasaan yang sudah lama ada dan berkembang di tengah kehidupan sosial masyarakat di Negeri Soya. Sedangkan dari kebijakan yang mendasari keberadaan KPHL mengisyaratkan adanya perijinan yang ditetapkan oleh Menteri Kehutanan dalam kawasan hutan seperti Ijin Usaha Pemanfaatan Hasil Hutan Kayu-Hutan Alam (IUPHHK-HA), Ijin Usaha Pemanfaatan Hasil Hutan Kayu-Hutan Tanaman (IUPHHKHT), Ijin Pemanfaatan Hasil Hutan Bukan Kayu (IPHHBK) dan Ijin Usaha Pemanfaatan Jasa Lingkungan.

\section{Status Tata Kuasa Penguasaan UPTD KPHL Unit XIV Kota Ambon}

Penetapan wilayah KPHL Unit XIV bermula dari Surat Keputusan Menteri Kehutanan Nomor SK.65/Menhut-II/2010 tanggal 28 Januari 2010 tentang Penetapan Wilayah Kesatuan Pengelolaan Hutan Lindung (KPHL) dan Kesatuan Pengelolaan Hutan Produksi (KPHP) di Provinsi Maluku dan dijabarkan dalam Peraturan Gubernur Maluku Nomor 64 Tahun 2017 tentang kedudukan, tugas dan fungsi susunan organisasi dan tata kerja Unit Pelaksanan teknis daerah Dinas dan Badan Daerah di Lingkungn Pemerintah Daerah Provinsi Maluku, yang didalamnya

\section{Status Tata Kuasa Penguasaan PEMDA}

Fasilitas PDAM yang terdapat di dusun Air Besar Negeri Soya dikelola oleh perusahaan Daerah PDAM dan DSA. Penetapan lokasi

- Berdasarkan Surat Pelepasan Tanah dari Wilhelminus A. Saptenno selaku pemilik lahan kepada Pimpinan Proyek peningkatan air bersih Maluku yang mewakili Departemen Pekerjaan Umum menjelaskan pembentukan organisasi pengelola KPHL dan KPHP pada 11 Kabupaten/Kota di Provinsi Maluku, maka UPTD KPHL Unit XIV kota Ambon diberi kewenangan untuk melaksanakan pengelolaan wilayah seluas \pm 9510.52 Ha sesuai lampiran Peta Surat Keputusan Menteri Kehutanan Nomor SK. 66/Menhut-II/2010 dan berpedoman pada tugas pokok dan fungsi $\mathrm{KPH}$ sesuai Peraturan Pemerintah Nomor 6 Tahun 2007 jo. Peraturan Pemerintah Nomor 3 Tahun 2008.

tersebut sebagai sumber air bersih karena memenuhi beberapa kriteria yaitu :

Kantor Wilayah Maluku Nomor 01/PH/08/1986 seluas 2064 meter untuk pembangunan $\mathrm{Bak}$ penampungan air bersih 

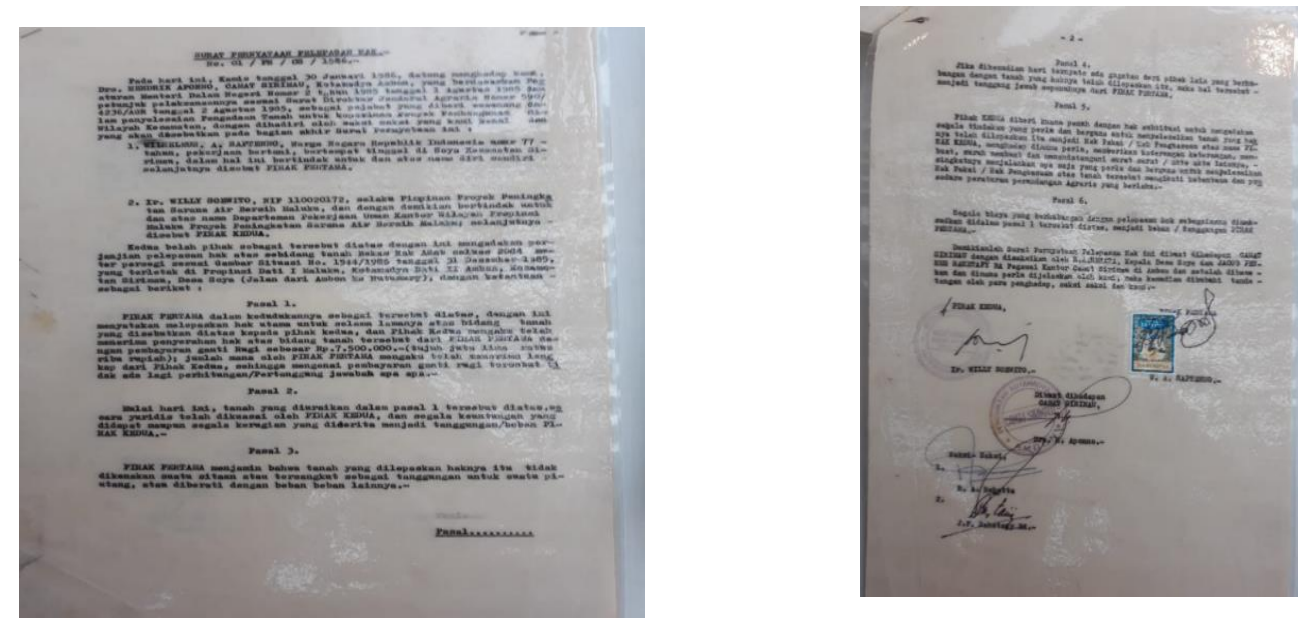

Gambar 1. Bukti Pemanfaatan lahan Pemerintah Kota Ambon

Pemanfaatan sumber air bersih oleh PDAM dan DSA di dalam petuanan marga Sapteno berdasarkan kepekatan yang dibangun antara pemerintah Negeri dan Pemerintah Kota Ambon.

\section{Status Tata Kuasa Penguasaan Masyarakat Adat}

Awal penguasaan tanah dan SDA masyarakat Negeri Soya diperoleh dari warisan leluhur mereka yang kemudian menjadi Tanah Hak Ulayat. Perkembangann selanjutnya pada jaman pemerintahan kolonial Belanda mengatur dan membagi lahan masyarakat tersebut menjadi hak milik lewat Register Dati Tahun 1814. Informasi yang didapat dari Pemerintah Negeri Soya bahwa berdasarkan Register Dati Tahun 1814 petuanan adat Negeri Soya dibagi menjadi
446 (empat ratus empat puluh enam) Dati yang dipimpin oleh 42 Kepala Dati yang keberadaannya masih diakui oleh masyarakat adat sampai sekarang ini. Kebanyakan sejarah di Kota Ambon menggunakan sejarah tutur dan bukan tertulis sehingga sistem penguasaan lahan oleh masyarakat di Negeri Soya hanya berdasarkan penunjukan secara lisan dan ditandai dengan batasan alam baik itu sungai, gunung, lembah , pohon, batu dll

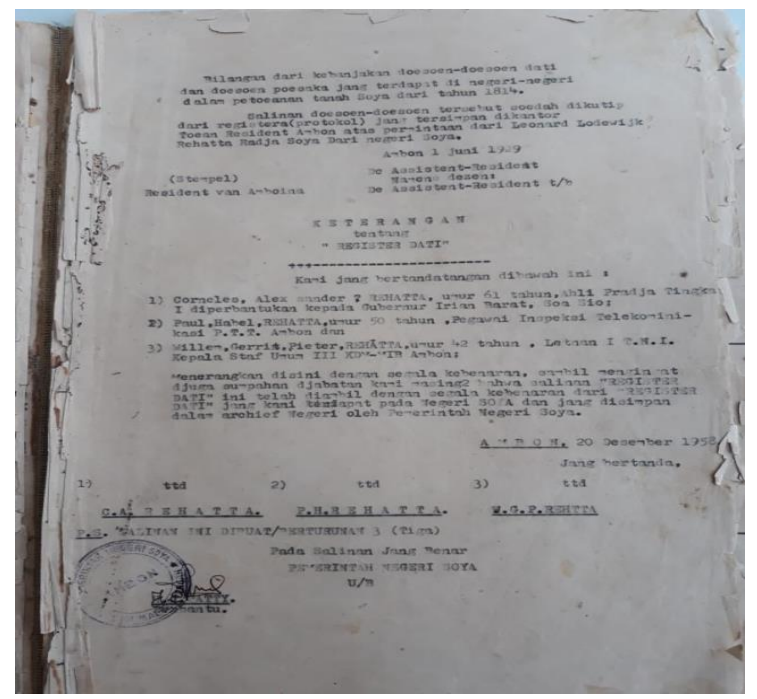

Gambar 2. Salinan Register Dati 1814 


\section{Status Tata Kelola Da KPHL Unit XIV Kota Ambon}

Galudra et al. (2006) menyatakan bahwa bentuk perencanaan pengelolaan (tata kelola) atas tanah dan SDA yang diklaim oleh masyarakat dapat berupa pemukiman, kebun dan hutan, sedangkan oleh pemerintah

\section{Status Tata Kelola UPTD KPHL Unit XIV Kota Ambon.}

Tata kelola UPTD KPHL Unit XIV, Berdasarkan Surat Keputusan Menteri Kehutanan Nomor SK.66/Menhut-II/2010 tanggal 28 Januari 2010 tentang Penetapan Wilayah Kesatuan Pengelolaan Hutan Lindung (KPHL). Kesatuan Pengelolaan Hutan Produksi (KPHP) di Provinsi Maluku dapat berupa rencana tata ruang wilayah. Hasil penelitian ini menunjukkan bahwa rencana pengelolaan (tata kelola) atas tanah dan SDA yang diklaim oleh UPTD KPHL Unit XIV, PEMDA Kota Ambon, Masyarakat Adat/Lokal dan Masyarakat pendatang cukup bervariasi.

dijabarkan dalam Peraturan Gubernur Maluku Nomor 64 Tahun 2017. Peraturan tersebut menjelaskan tentang kedudukan, tugas dan fungsi susunan organisasi dan tatakerja UPTD Dinas dan Badan Daerah di lingkungn Pemerintah Daerah Provinsi Maluku, yang di dalamnya menjelaskan pembentukan organisasi pengelola KPHL dan KPHP pada 11 Kabupaten/Kota di Provinsi Maluku.

Tabel 2. Penyelarasan Antara Rancangan Blok pada Wilayah KPHL dan KPHP dengan Arahan Pemanfatan pada RKTN/RKTP/RKTK.

\begin{tabular}{|c|c|c|c|}
\hline No & $\begin{array}{c}\text { Arahan Pemanfaatan pada } \\
\text { kawasan } \\
\text { hutan menurut } \\
\text { RKTN/RKTP/RKTK }\end{array}$ & $\begin{array}{c}\text { Pembagian Blok pada } \\
\text { Wilayah KPHL dan KPHP }\end{array}$ & Keterangan \\
\hline 1. & \multicolumn{3}{|c|}{ Blok pada Wilayah KPHL dan KPHP yang berfungsi HL } \\
\hline 1.1 & $\begin{array}{l}\text { Kawasan untuk } \\
\text { Perlindungan Hutan Alam } \\
\text { dan Lahan Gambut }\end{array}$ & $\begin{array}{l}\text { - Blok Inti } \\
\text { - Blok Pemanfaatan } \\
\text { - Blok Khusus }\end{array}$ & $\begin{array}{l}\text { Kawasan untuk perlindungan Hutan } \\
\text { Alam dan Lahan Gambut (dalam } \\
\text { RKTN/RKTP/RKTK) menjadi acuan } \\
\text { awal dalam merancang Blok yang } \\
\text { dapat berupa Blok Inti atau Blok } \\
\text { Pemanfaatan atau Blok Khusus pada } \\
\text { HL sesuai potensi yang ada. }\end{array}$ \\
\hline 1.2 & $\begin{array}{l}\text { Kawasan untuk } \\
\text { Rehabilitasi }\end{array}$ & $\begin{array}{l}\text { - } \text { Blok Inti } \\
\text { - } \text { Blok Pemanfaatan } \\
\text { - } \text { Blok Khusus }\end{array}$ & $\begin{array}{l}\text { Kawasan rehabilitasi (dalam } \\
\text { RKTN/RKTP/RKTK) menjadi acuan } \\
\text { awal dalam merancang Blok yang } \\
\text { dapat berupa Blok Inti atau Blok } \\
\text { Pemanfaatan atau Blok Khusus pada } \\
\text { HL sesuai potensi yang ada. }\end{array}$ \\
\hline 2. & Blok pada Wilayah KPHI & dan KPHP yang berfungsi & \\
\hline 2.1 & $\begin{array}{l}\text { Kawasan untuk } \\
\text { Perlindungan Hutan Alam } \\
\text { dan Lahan Gambut }\end{array}$ & $\begin{array}{l}\text { - } \text { Blok Perlindungan } \\
\text { - } \text { Blok Pemanfaatan } \\
\text { Kawasan, Jasa } \\
\text { Lingkungan dan HHBK } \\
\text { - } \text { Blok Khusus }\end{array}$ & $\begin{array}{l}\text { Kawasan untuk perlindungan Hutan } \\
\text { Alam dan Lahan Gambut (dalam } \\
\text { RKTN/RKTP/RKTK) menjadi acuan } \\
\text { awal dalam merancang Blok yang } \\
\text { dapat berupa Blok Perlindungan atau } \\
\text { Blok Pemanfaatan Kawasan, jasa } \\
\text { Lingkungan dana HHBK atau Blok } \\
\text { Khusus pada HP sesuai potensi yang } \\
\text { ada. }\end{array}$ \\
\hline 2.2 & $\begin{array}{l}\text { Kawasan untuk } \\
\text { Rehabilitasi }\end{array}$ & $\begin{array}{ll}\text { - } & \text { Blok Perlindungan } \\
\text { - } & \text { Blok Pemanfaatan } \\
\text { Kawasan, Jasa }\end{array}$ & $\begin{array}{l}\text { Kawasan rehabilitasi (dalam } \\
\text { RKTN/RKTP/RKTK) menjadi acuan } \\
\text { awal dalam merancang Blok yang }\end{array}$ \\
\hline
\end{tabular}




\begin{tabular}{|c|c|c|c|}
\hline No & $\begin{array}{c}\text { Arahan Pemanfaatan pada } \\
\text { kawasan } \\
\text { hutan menurut } \\
\text { RKTN/RKTP/RKTK }\end{array}$ & $\begin{array}{c}\text { Pembagian Blok pada } \\
\text { Wilayah KPHL dan KPHP }\end{array}$ & Keterangan \\
\hline & & $\begin{array}{ll}\text { Lingkungan dan HHBK } \\
\text { - } \text { Blok Pemanfaatan } \\
\text { HHK-HT } \\
\text { - } \text { Blok pemberdayaan } \\
\text { Masyarakat } \\
\text { - } \text { Blok Khusus }\end{array}$ & $\begin{array}{l}\text { dapat berupa Blok Perlindungan atau } \\
\text { Blok Pemanfaatan Kawasan, Jasa } \\
\text { Lingkungan dana HHBK atau Blok } \\
\text { Pemanfaatan HHK-HT atau Blok } \\
\text { Pemberdayaan Masyarakat atau Blok } \\
\text { Khusus pada HP sesuai potensi yang } \\
\text { ada. }\end{array}$ \\
\hline 2.3 & $\begin{array}{l}\text { Kawasan untuk } \\
\text { pengusahaan hutan skala } \\
\text { besar }\end{array}$ & $\begin{array}{ll}\text { - } & \text { Blok Perlindungan } \\
\text { - } & \text { Blok Pemanfaatan } \\
& \text { Kawasan, Jasa } \\
& \text { Lingkungan dan HHBK } \\
\text { - } & \text { Blok Pemanfaatan } \\
& \text { HHK-HA } \\
\text { - } & \text { Blok Pemanfaatan } \\
& \text { HHK-HT } \\
\text { - } & \text { Blok pemberdayaan } \\
& \text { Masyarakat } \\
\text { - } & \text { Blok Khusus }\end{array}$ & $\begin{array}{l}\text { Kawasan untuk pengusahaan hutan } \\
\text { skala besar (dalam } \\
\text { RKTN/RKTP/RKTK) menjadi acuan } \\
\text { awal dalam merancang Blok yang } \\
\text { dapat berupa Blok Perlindungan atau } \\
\text { Blok Pemanfaatan Kawasan, Jasa } \\
\text { Lingkungan dana HHBK atau Blok } \\
\text { Pemanfaatan HHK-HA, atau Blok } \\
\text { Pemanfaatan HHK-HT, atau Blok } \\
\text { Pemberdayaan Masyarakat atau Blok } \\
\text { Khusus pada HP sesuai potensi yang } \\
\text { ada. }\end{array}$ \\
\hline 2.4 & $\begin{array}{l}\text { Kawasan untuk } \\
\text { pengusahaan hutan skala } \\
\text { kecil }\end{array}$ & $\begin{array}{l}\text { - } \text { Blok Perlindungan } \\
\text { - } \text { Blok Pemanfaatan } \\
\text { Kawasan, Jasa } \\
\text { Lingkungan dan HHBK } \\
\text { - } \text { Blok Pemanfaatan } \\
\text { HHK-HT } \\
\text { - } \text { Blok pemberdayaan } \\
\text { Masyarakat } \\
\text { - } \text { Blok Khusus }\end{array}$ & $\begin{array}{l}\text { Kawasan untuk pengusahaan hutan } \\
\text { skala kecil (dalam } \\
\text { RKTN/RKTP/RKTK) menjadi acuan } \\
\text { awal dalam merancang Blok yang } \\
\text { dapat berupa Blok Perlindungan atau } \\
\text { Blok Pemanfaatan Kawasan, Jasa } \\
\text { Lingkungan dana HHBK, atau Blok } \\
\text { Pemanfaatan HHK-HT atau Blok } \\
\text { Pemberdayaan Masyarakat atau Blok } \\
\text { Khusus pada HP sesuai potensi yang } \\
\text { ada. }\end{array}$ \\
\hline
\end{tabular}

Kegiatan pengelolaan hutan dan hasil hutan dalam wilayah KPH dapat merupakan kombinasi antara pemegang ijin dan pengelola $\mathrm{KPH}$, oleh karena itu pengelolaan hutan seperti tata hutan, pemanfaatan, rehabilitasi, perlindungan, dan konservasi hutan perlu dipertimbangkan kebutuhan bersama di dalam

\section{Status Tata Kelola PEMDA Kota Ambon.}

Pembangunan KPH di Maluku membagi habis hutan di Maluku ke dalam unit-unit pengelolaan yang membutuhkan pengintegrasian semua sektor kedalam unit pengelolaan. Pengembangan KPH tidak dapat berdiri sendiri mengingat Wilayah KPHL Unit XIV khususnya Hutan Lindung Gunung Sirimau secara administrative berada di
KPH. Dengan demikian UPTD KPHL Unit XIV merupakan pihak yang memiliki kepentingan terhadap sumber daya yang ada dalam wilayahnya untuk dapat dikelola sesuai dengan peraturan perundangan yang berlaku. didalam wilayah Pemerintah Kota Ambon, untuk itu dibutuhkan kerjasama antar sektor sehingga tuntutan pengisian tata ruang nasional, provinsi dan kota dapat dilaksanakan sebagaimana mestinya, dengan tujuan utama menghasilkan kelestarian dengan pengelolaan yang lebih akurat pada unit-unit pengelolaan yang kecil, maka 
diharapkan bahwa kebutuhan ruang hijau sebesar minimal $30 \%$ dapat terjaga, di sisi lain kesejahteraan masyarakat di sekitar hutan dapat terjamin dengan menggunakan landasan aspek legal yaitu Peraturan Daerah Kota Ambon Nomor 24 Tahun 2012 tentang Rencana Tata Ruang Wilayah Tahun 20112031. Pemerintah Kota Ambon menerapkan salah satu kebijakan dan strategi pemanfaatan jasa kawasan lindung yaitu pemnfaatan air bersih pada kawasan lindung Gunung

\section{Status Tata Kelola Masyarakat Adat}

Pengelolaan tanah dan SDA yang diklaim oleh masyarakat adat pada dasarnya terbagi menjadi pemanfaatan untuk lahan hutan dan lahan perkebunan masyarakat yang telah dikuasai dari jaman leluhur mereka. Penguasaan tanah dan SDA pada kawasan hutan berupa lahan yang telah ditanami dengan tanaman umur panjang oleh

Status Tata Perijinan Dalam Wilayah KPHL Unit XIV Kota Ambon

Tata perijinan yang berlaku pada KPHL Unit XIV suatu klaim penguasaan lahan pada masyarakat didasari pada kebiasan yang disepakati dalam kehidupan sosial mereka, sedangkan oleh pemerintah didasarkan pada peraturan perundangan yang berlaku dan diterbitkan oleh pihak yang

Status Tata Perijinan Menurut UPTD KPHL Unit XIV Kota Ambon

Aturan mengamanatkan bahwa pemanfaatan hutan dan hasil hutan diwujudkan dalam bentuk ijin. Pada wilayah KPHL Unit XIV Kota Ambon dapat dimanfaatkan melalui mekanisme perijinan seperti: Ijin Usaha Pemanfaatan Hasil Hutan Bukan Kayu (IUPHHBK), Ijin Usaha Pemanfaatan Hasil Hutan Jasa Lingkungan

Status Tata Perijinan Menurut Masyarakat Adat
Sirimau di dusun air besar Negeri Soya dimana terdapat sumber air bersih dimanfaatkan oleh Pemerintah Kota Ambon yaitu mata air Waniuw dengan kapasitas $83 \mathrm{~m}^{3} / \mathrm{jam}$ yang disalurkan untk kebutuhan air bersih masyarakat Kota Ambon yang merupakan salah satu target Sustainable Development Goals (SDGs) yang diterapkan Pemerintah Kota Ambon yang pelindungan dan pemeliharaan diatur di dalam RTRW Pemerintah Kota Ambon.

masyarakat Negeri Soya, yang sudah ada jauh sebelum pemerintah menetapkan status kawasan. Biasanya masyarakat lokal mengklaim suatu lokasi tanah dengan menanam pohon, merawatnya sampai menghasilkan buah untuk kemudian dimanfaatkan untuk peningkatan ekonomi masyarakat.

berwewenang. Pada klaim penguasaan tanah dan SDA dalam wilayah terdapat beberapa tata perijinan yang berlaku sesuai dengan kebiasaan masyarakat Adat serta peraturan pemerintah terkait dengan pengelolaan hutan seperti Peraturan Pemerintah Nomor 6 Tahun 2007 jo Peraturan Pemerintah Nomor 3 Tahun 2008 tentang Tata Hutan, Penyusunan Rencana Pengelolaan Hutan, serta Pemanfaatan Hutan.

(IUPHH Jasling), Pemberdayaan masyarakat dapat dilakukan melalui pengalokasian dan penetapan kawasan hutan tertentu dalam wilayah KPHL oleh pemerintah sebagai hutan kemasyarakatan, hutan adat, hutan desa dan kawasan hutan dengan tujuan khusus (KHDTK) berdasarkan usulan KPH, sesuai Peraturan Pemerintah Nomor 6 tahun 2007 jo Peraturan Pemerintah Nomor 3 tahun 2008 pasal 11 ayat (2).

Pemanfaatan lahan hutan oleh masyarakat adat umumnya telah dilakukan pada petuanan marga/soa namun ada juga masyarakat pendatang yang memanfaatkan 
lahan marga/soa lain untuk lahan pemukiman maupun aktivitas berkebun. Luasan dan lokasi lahan yang diijinkan untuk dimanfaatkan juga harus sesuai arahan dari pemilik lahan. Rata-rata lahan yang dipinjam pakaikan untuk masyarakat dusun Air Besar dan dusun Kahena dimanfaatkan untuk ditanami dengan tanaman umur pendek seperti singkong, ubi, nenas, kacang tanah, jagung dan labu dengan luasan yang beragam, mulai dari $10 \times 15 \mathrm{~m}$ sampai $20 \times 25$ yang hasilnya dijual untuk peningkatan ekonomi.
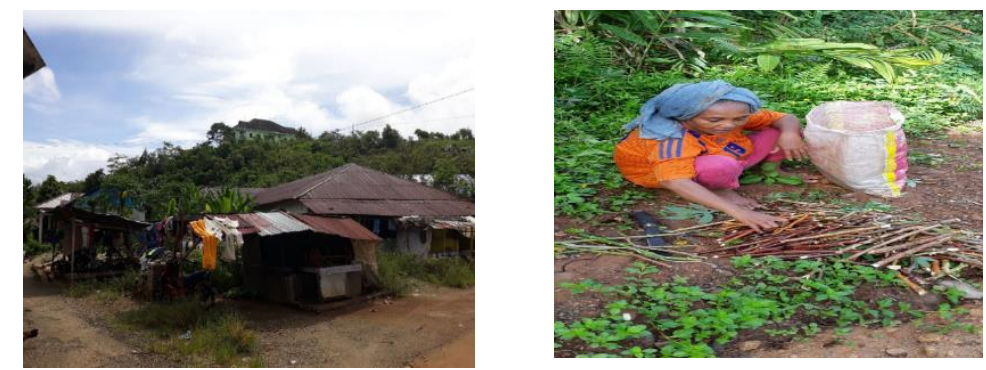

Gambar 3 Bentuk Izin Pemafaatan Lahan untuk aktifitas perkebunan dan pemukiman dari Pemerintah Negeri Soya kepada masyarakat pendatang

\section{Analisis Potensi Konflik}

Kepastian hak atas tanah dan SDA yang diklaim para pihak dan kebijakan yang mengakui atau memperkuat klaim parapihak dapat saling terintegrasi. Parapihak utama yang memiliki kepentingan dan dasar klaim yang berbeda terhadap tanah dan SDA yang dikuasai adalah: 1) UPTD KPHL Unit XIV mengklaim penguasaan wilayah KPHL berdasarkan Surat Keputusan Menteri Kehutanan Nomor SK.65/Menhut-II/2010 tanggal 28 Januari 2010 tentang Penetapan Wilayah Kesatuan Pengelolaan Hutan Lindung (KPHL) dan Kesatuan Pengelolaan Hutan Produksi (KPHP) Produksi di Provinsi Maluku dan dijabarkan dalam Peraturan Gubernur Maluku Nomor 64 Tahun 2017 tentang kedudukan, tugas dan fungsi susunan organisasi dan tatakerja Unit Pelaksanan teknis daerah Dinas dan Badan Daerah di Lingkungn Pemerintah Daerah Provinsi Maluku. 2) klaim masyarakat adat, berdasarkan Register Dati Tahun 1814 yang diterbitkan oleh Pemerintah Kolonial Belanda yang keabsahannya diakui sampai sekarang dan pengelolaan tanah dan SDA oleh masyarakat lokal sudah ada jauh sebelum adanya penetapan yang di wilayah KPHL Unit XIV, berdasarkan sejarahnya, penguasaan tanah dan SDA oleh masyarakat adat sudah ada sebelum berdirinya negara dan sebelum aturan Kehutanan terkait pengelolaan hutan diterbitkan. Klaim penguasaan tanah dan SDA saat ini merupakan hasil pewarisan kepemilikan secara turun temurun. Dalam penelitian ini pihak-pihak yang secara de jure dan de facto mengklaim penguasaan tanah dan SDA dalam wilayah adalah UPTD KPHL Unit XIV dan Masyarakat adat. Untuk itu dibutuhkan koordinasi antar pihak yang saling klaim terkait kepastian tenurial dalam penataan dan pengelolaan KPHL Unit XIV Kota Ambon.

\section{KESIMPULAN}

Kesimpulan dalam Penelitian ini : 
1. Analisis potensi konflik didalam wilayah kelola UPTD KPHL Unit XIV dengan menggunakan metode RaTA dengan pendekatan basis legitimasi klaim berupa pendekatan tata kelola, tata kuasa dan tata perijinan yang melekat pada para pihak memiliki sifat-

2. Potensi konflik berupa bukti klaim para pihak secara de jure dan de facto atas sistem penguasaan tanah dan sumber daya alam sangat nyata terjadi antara

\section{DAFTAR PUSTAKA}

Anonim, 2001, Surat Keputusan Menteri Kehutanan Nomor 10327/KptsII/2002, tanggal 30 Desember 2002 tentang Penetapan Kawasan Hutan Lindung Gunung Sirimau, Departemen Kehutanan Direktorat Jenderal Planologi Republik Indonesia. Jakarta,

Afiff, S. 2005. Tinjauan Atas Konsep "Tenure Security", Dengan Beberapa Rujukan Pada KasusKasus di Indonesia. Wacana $J$ Ilmu Sosial Transformatif 20:227-249.

Alwasilah A.C. 2002. Pokoknya Kualitatif: Dasar-Dasar Merancang dan Melakukan Penelitian Kualitatif. Jakarta: Pustaka Jaya.

BSN (Badan Standarisasi Nasional), 2013, SNI 7896:2013 tentang Pengolahan Hutan Lindung Lestari. [Internet]. [diunduh 2019 Juni 9]. Tersedia pada: http://staneclime.org/uploads/atta ch/SNI_7896-2013.pdf .

Bungin B. 2006. Analisis data Penelitian Kualitatif. Pemahaman Filosofis dan Metodologis ke Arah Penguasaan Model Aplikasi. PT. Raja Grafindo Persada. Jakarta.

Galudra G Pasya G, Sirait M, Fay C. 2006. Rapid Land Tenure Assessment (RaTA). Panduan Ringkas Bagi Praktisi. Bogor : World sifat kepentingan yang saling bersilangan (web of intersecting interests) yang berpotensi melahirkan konflik atas penguasaan dan pemanfaatan tanah dan sumber daya alam dalam wilayah pengelolaan KPHL Unit XIV Kota Ambon masyarakat adat dan pihak UPTD KPHL Unit XIV Kota Ambon.

Agroforestry Centre Southeast Asia Regional Program.

Jacob A, 2009, Alternatif Pengelolaan Lahan Optimal untuk Pelestarian Sumber Daya Air di Pulau Ambon (Disertasi Institut Pertanian Bogor. Bogor.

$$
\begin{array}{ccr}
\text { Kartodihardjo, H. } & 2014 & \text { Strategi } \\
\text { Pengembangan } \quad \text { KPH } & \text { dan } \\
\text { Perubahan } & \text { Struktur Kehutanan } \\
\text { Indonesia. } & \text { Direktorat } & \text { Jenderal } \\
\text { Planologi } & \text { Kehutanan. } & \text { KLHK, } \\
\text { Jakarta. Desember 2014. }
\end{array}
$$

KPHL Unit XIV. 2018. Draft Rencana Pengelolaan Hutan Jangka Panjang (RPHJP). KPHL Unit XIV Kota Ambon 2018-2027. Ambon. 